Khalil Ullah Mohammad ${ }^{*}$, Shin-Ichi Nishiyama **

\section{An Empirical Investigation into the Effect of Explicit Deposit Insurance and Design on the Liability Structure of Banks}

\begin{abstract}
This paper provides an insight into the behaviour of the liability side of bank balance sheet in response to explicit deposit insurance. It is an empirical investigation into the choice of a rational bank maximizing its bank value in terms of deposit and non-deposit liabilities after the implementation of explicit deposit insurance. The paper tests how banks' liabilities are affected because of the safety net and its design. Banks lower their leverage ratio as a response to the explicit deposit insurance. The paper finds evidence of depositor shifting funds between the types of deposits in the bank as a result of the explicit deposit insurance. It provides evidence of the importance of setting the right coverage in order to prevent the adverse effects that deposit insurance induces. It studies how the safety net design features affect the bank liability structure. The study finds that besides the explicit deposit insurance, the bank liability structure is affected by factors like tax expense, bank size, overheads, and dividend payout.
\end{abstract}

Keywords: Bank Liability Structure; Explicit Deposit Insurance; Leverage

JEL classification numbers: G280, G210, C220
${ }^{*}$ Bahria University, Islamabad, Pakistan

E-mail:

Khalilullah.buic@bahria.edu.pk

${ }^{* *}$ Kobe University, Japan

E-mail:

Nishiyama@econ.kobe-u.ac.jp 


\section{Introduction}

Compared to the wealth of studies that focus on bank profitability and safety nets, there has been considerably less focus placed on its impact on the distribution of funds available in terms of time durations. In developing economies where capital markets are underdeveloped and SMEs face major financing constraints, this issue is relevant and carries great importance.

This study answers the research question of how liability structures of banks are affected by the implementation of explicit deposit insurance. It aims to identify how implementation of explicit deposit insurance shifts the type of funding available to banks in countries and its impact on the economy as a whole.

Over the past 2 decades, the banking sector has seen an increase in the vigilance of central regulatory authorities. There has been an explosion of bank regulation through the use of explicit deposit insurance in the wake of the financial crisis. Global monetary and financial institutions like the IMF have taken the leading role in trying to enforce this policy across the developing countries as well. Many Asian countries have finally caught on with the western FDIC and similar European bank deposit insurance systems. Some countries have introduced the explicit deposit insurance safety net while many of them are considering implementing the program.

Developing safety nets, however, is not such a straightforward task and countries have experimented with how to set them up according to their own environment. This boom in the adoption of the explicit insurance scheme over the past 15 years has provided the researching community with an improved and detailed crosscountry dataset which this paper exploits to study the effect its implementation and its design features have which have not been available previously for empirical analysis. Over the decades, literature has tried to explain the choice of funding by firms trying to optimize their value. The banking model is also faced with a similar choice of funding for its intermediation purposes.

Market discipline literature provides evidence of how deposits interest rates and deposit growth is affected by explicit deposit insurance. Although deposit growth has been examined in detail, how a bank adjusts its leverage and liability structure in response to policy needs further examination. Since highly leveraged banks have higher risk-taking incentives, the explicit deposit insurance, if not properly implemented, is theorized to lead to an aggravation in the adverse effects of moral hazard. 
This paper investigates bank behaviour as it optimizes its leverage and liability ratio as a response to the introduction of explicit deposit insurance and its design features. The theory on bank liability structure by Sundaresan and Wang (2014) and the effect of explicit deposit insurance as an insight into the funding choice of banks is tested in the study.

Cross-country empirical evidence on how funds are shifted between the different funded choices, how the banks' balance sheet liability side changes and how deposit insurance design features are affecting them is still not available and there are important considerations before the decision to implement the explicit deposit insurance program. This paper tries to fill this gap.

\section{Review of Literature}

Immense work on deposit insurance was done in the 1980s. Among them the Diamond and Dybvig (1983) model on bank runs is a seminal paper that most empirical researches on deposit insurance trace back to. They suggest that explicit deposit insurance is the only way to prevent a bank run without preventing the bank from performing its role as a liquidity provider. With their downward risk secured with the help of deposit insurance the banks then get involved in undue risk taking. Within 30 years this policy has been introduced as a safety net in more than 30 countries. The next big question that needed to be answered by researchers was how to fairly price deposit insurance. Buser, Chen and Kane (1981) argued against the use of flat rate deposit insurance premiums. They proposed risk rated explicit premium in the context of the FDIC. Merton (1977) provided insight into pricing deposit insurance premium by modelling using option pricing. Cull, Senbet and Sorge (2002) investigated deposit insurance in context of financial inclusion its role in improve the deposit base of financial institutions.

Among recent work done on deposit insurance is a research by the research department of the World Bank. They developed a cross-country database of deposit insurance programs and their design features that were in place in 178 countries of the world (Demirgüç-Kunt \& Detragiache, 2002). This database, the first of its type, allowed empirical research work to be carried out on the effects of deposit insurance. They carried out an analysis of 61 countries and investigated the effect of deposit insurance on the likelihood of a banking crisis emergence. They found that weak institutional environment and deregulated interest rates do not increase the likelihood of deposit insurance increasing the stability of the banking system. 
Demirgüç-Kunt and Kane (2002) investigated where the deposit insurance works and they found that low institutional and financial development do not do well under the explicit deposit insurance scheme questioning the wisdom of encouraging countries to adopt explicit deposit insurance without improving the supervisory environment. Similarly, Demirgüç-Kunt and Huizinga (2004) carried out a cross-country analysis of how deposit interest rates fall after the implementation of explicit deposit insurance. They, however, found no evidence of whether the growth rate of deposits increases or decreases after the implementation of the policy. Gonzalez (2005) also found that risk-taking behaviour would increase in the banking system with deposit insurance. Kim and Han (2014) also found evidence of moral hazard induced as a result of deposit insurance in ASEAN countries. Similarly Chernykh and Cole (2011) investigated how deposit insurance impacted the banks' role of financial intermediation. However, the majority of empirical work has focused on the market disciplining as a result of the safety net. (Martinez \& Schmukler, 2001; Keiko \& Masahiro, 2004; Fueda \& Konishi, 2007; Qian, Zhang and Zeng (2017); Assa \& Okhrati. 2018; Ioannidou \& De Dreu, 2019) are some of the studies that examine market discipline by banks as a result of deposit insurance focusing on interest rates and deposit growth. A similar study by Tsuru (2003) investigated policy implications of deposit insurance design in Japan.

A relatively new stem of studies originated from the seminar paper by Gropp and Heider (2010) on bank capital structure, which was an extension of findings of Bradley and Shibut (2006) on how liability structures were impacted by deposit insurance. As a result Sundaresan and Wang (2014) proposed, a theoretical model on the banks' liability structure. They analyse the banks'value-maximizing liability structure. They investigate the combination of deposit and subordinated debt that is value-maximizing for the bank and how the introduction of explicit deposit insurance affects it.

\subsection{Sundaresan and Wang (2014) Model}

Bradley and Shibut (2006) had previously studied how liability structures of federally insured institutions were different from others. This led to further research by Sundersaresan and Wang (2014) developing a model that optimizes the banks value based on their liability choice. They model the banks' choice between deposits and subordinated debt under constraints of bankruptcy. It incorporates Merton (1977) deposit insurance fair pricing model involving the calculation of probability of default and Leland (1994) model maximizing a firm's value based on debt alone. Including deposit taking function of the bank into the Leland 
(1994) model results in a value function that they then maximize to find the optimal level deposits and subordinated loans for a value-maximizing bank. Below is a simplification of the Sundaresan and Wang (2014) model that forms the theoretical base for the empirical study.

The cost of deposits is defined as $C$; $r$ is the risk-free rate and $\eta$ is the cost incurred by the bank in providing its services. The subordinated debt $C_{1}$ costs the bank the risk-free rate $r$ plus the spread $s$ for incurring the extra risk $D$ is the total deposits and $D_{1}$ represents the subordinated debt.

$C=D(r-\eta)$

Cost of Deposit= Total Deposits (Risk free rate - services charges)

$C_{1}=D_{1}(r+s)$

Cost of Subordinated Debt= Total Debt (Risk free rate + risk spread)

The dividend paid to the equity holders is represented by asset cash flow minus the cost of deposits and subordinated debt after the tax and the insurance cost I is represented in equation 3 .

$\delta V-(1-\tau)\left(I+C+C_{1}\right)$

The optimal choice for liability structure is based on $\left(C, C_{1}, I\right)$ with explicit deposit insurance. In deciding the liability structure of a bank, the frictions the bank faces are risk of default, cost of deposit insurance and its charter value. In their modelling of the optimal banks' liability choice the bank faces three types of defaults: Depositor run, closure by the regulator and the endogenous default.

Depositor run happens when the value after the liquidation, (1- $\alpha) \mathrm{Va}$, is lesser then the deposits where $\alpha$ is the liquidation costs.

$V_{a} \geq D /(1-\alpha)$

$\mathrm{V}_{\mathrm{a}}$ must therefore be more than equal to $\kappa \mathrm{D}$ where $\kappa$ is defined as $(1 / 1-\alpha)$ forming the threshold for default in terms of asset value.

Regulatory closure happens if the total capital value of the bank falls below $2 \%$ of its asset value. They define the total capital as tangible equity plus the subordinated debt.

$\mathrm{V}-\mathrm{D}=2 \% \mathrm{~V}_{\mathrm{a}}$ where $\mathrm{V}_{\mathrm{a}}$ is the threshold when it is closed. 
$\mathrm{Va}=\kappa \mathrm{D}$ with $\kappa>=1$ bank closed

When the regulator closes the bank at $\mathrm{V}_{\mathrm{a}}$ the model assumes that its cost is different from the cost of bankruptcy in case of a bank run and they define it as $\beta$. FDIC closure liquidation cost is therefore $\beta \mathrm{V}_{\alpha}$. When liquidation happens, the regulators need to pay the depositors $\mathrm{D}$ and if the deposits are more than the liquidation costs, the bank loses. To cover for such losses the regulator charges the bank a risk based insurance premium I. The loss the insurance company faces is $\mathrm{D}-(1-\beta) \mathrm{V}_{\alpha}$ if $(1-\beta) \mathrm{V}<\mathrm{D}$ otherwise the loss is 0 .

The third type of default is when the equity holders choose to default which maximizes equity value. This default happens before the bank run or a closure by the regulators. This point of default that maximizes equity is an extension of Leland (1994) for the case of banks and is referred to as endogenous default in the model $\mathrm{V}_{\mathrm{d}}$. Default is triggered when the asset value falls below this level or one of the prior default types occurs.

$V_{b}=\max \left\{V_{d} V_{a}\right\}$

They define the recovery cost as $(1-\Phi) \mathrm{V}_{\mathrm{a}}$ where $\Phi$ is $\alpha$ or $\beta$. The payoff function for the default is

Payoff $=[(1-\Phi) V a-D]^{+}$

Using the Merton (1977) definition, the model uses assumption of the bank assets following a stochastic Ito's process shown in equation 7.

$d V=(r-\delta) V d t+\sigma V d W$

$\mathrm{dW}$ is a wiener process, $\sigma$ is the volatility of asset and $\mathrm{r}$ is risk free rate. $\mathrm{P}_{\mathrm{b}}$ is the probability of default they define as the state price of bankruptcy as a solution taken from Merton (1977). The general solution to the equation is $\mathrm{P}_{\mathrm{b}}=\mathrm{a}_{1} \mathrm{~V}^{-\lambda}+\mathrm{a}_{2} \mathrm{~V}^{-\lambda}$ 'with boundary conditions $\mathrm{P}_{\mathrm{b}}\left(\mathrm{V}_{\mathrm{b}}\right)=1$ and $\operatorname{Lim}_{\mathrm{V}-\infty} \mathrm{P}_{\mathrm{b}}(\mathrm{V})=0$.

$\lambda$ is the positive square root of Itô 's lemma method " $1 / 2 \sigma^{2} \lambda(1+\lambda)-(r-\delta) \lambda-r=0$ "

$\mathrm{P}_{\mathrm{b}}=\left[\mathrm{V}_{\mathrm{b}} / \mathrm{V}\right]^{\lambda}$

The positive root is $\lambda=2 \mathrm{r} / \sigma^{2}$

The bank's liability choice (I, C, $C_{1}$ ) effect the value of the bank because it affects the state price and the boundary of when the bank faces bankruptcy. They start 
by defining the bankruptcy boundaries first. They start by deriving the bank run asset volume

$V_{a}=\kappa C /(r-\eta)$

The equation is derived by using $\mathrm{V}_{\mathrm{a}}=\mathrm{V}_{\mathrm{b}}=\kappa \mathrm{D}$ and $\mathrm{C}=(\mathrm{r}-\eta) \mathrm{D}$.

$V_{d}=(1-\tau)[\lambda /(1+\lambda)]\left(I+C+C_{1}\right) / r$

The default boundary is defined as $\mathrm{V}_{\mathrm{b}}$ that is a maximum of $\mathrm{V}_{\mathrm{a}}$ or $\mathrm{V}_{\mathrm{d}}$. They prove that when $\mathrm{V}_{\mathrm{a}}=\mathrm{V}_{\mathrm{d}}$ the equity value is maximized. The bank closes before it defaults if the asset value $\mathrm{V}$ falls down to $\mathrm{V}_{\mathrm{a}}$ before $\mathrm{V}_{\mathrm{b}}$.

$E=V-\frac{(1-\tau)\left(1-P_{b}\right)\left(I+C+C_{1}\right)}{r}+P_{b} V_{b}$

Equity $=$ AssetValue-AfterTaxCostofLiabilities+CostofInsurance

The equity value is in fact the asset value, which remains after the liabilities, and cost of insurance is deducted.

$D_{1}=\frac{\left(1-P_{b}\right) C_{1}}{r}+P_{b}\left[(1-\phi) V_{b}-D\right]^{+}$

SuboridinatedDebt=CouponPayment + ExpectedReturnIfDefaults

The general solution for subordinated debt is used along with the boundary conditions for subordinated debt to arrive at equation (11), which represents the subordinated debt, is composed of the coupon payments and the expected return given that there is default.

$\mathrm{F}$ is value of the bank the model defined as the sum of total liabilities (deposits and subordinated debt) and equity. The theorem models the bank value by substituting the equity and subordinated debt into the definition of F.

$F=E+D+D 1$

Bank Value=Equity + SubordinatedDebt+Deposits

$D=\frac{C}{r}-\eta$

The theorem models the bank value by substituting the equity and subordinated debt and deposit into the definition of $\mathrm{F}$, 
$F=V-P_{b} \min \left\{\phi V_{b}, V_{b}-D\right\}+\frac{\left(1-P_{b}\right)\left[\frac{C_{1} \eta}{r-\eta}+\tau\left(I+C+C_{1}\right)-I\right]}{r}$

BankValue $=$ Assets-ExpectedDefaultLoss+AfterTaxBenefit

The model uses these to maximize the bank value F. Deposit insurance and the deposit servicing cost are important factors that they identify as detrimental to an increase in bank value along with factors like tax saving. The insurance price I is exogenously decided in equation 13 . They model I as an endogenous variable the details of which are available in their paper.

$I=r[1-(1-\beta) \kappa]^{+} D P_{a} /\left(1-P_{a}\right)$

The function $\mathrm{F}$ is then maximized with respect to $\mathrm{Cl}$ and $\mathrm{C}$, which are the costs of subordinated debt and deposits, respectfully, to get their optimal levels. $\mathrm{P}_{\mathrm{b}}{ }^{*}$ is the optimal state price of bankruptcy.

$C^{*}=(r-\eta) V P_{b}^{* 1 / \lambda} / \kappa$

$C_{1}^{*}=r V P_{b}^{* 1 / \lambda}\left[\frac{1+\lambda}{(1-\tau) \lambda}-\frac{r-\eta}{r \kappa}-\omega\left[\frac{1}{\kappa}-(1-\beta)\right]^{+} \frac{P_{b}^{*}}{1-P_{b}^{*}}\right]$

Equation 7 and 8 are the optimal levels of deposits and subordinated debt after the insurance is priced endogenously in the model. Dividing them they arrive at the optimal liability ratio. They then go on to quantify the optimal bank leverage and come up with their inferences of how the liability and leverage structure is affected by deposit insurance.

Their predictions for the optimal liability structure in response to the Explicit Deposit Insurance safety net is that the leverage ratio (defined as the total liability to total bank assets) increases as the banks engage in riskier business. They predict that, if there is a low tax regime, the decrease in subordinated debt is higher than the increase in the deposits. This is also coming from an increase in asset value because of the decrease in taxes. They describe the main purpose of the subordinated debt or the non-deposit liability part of the liability structure of the bank is to take advantage of the tax benefit. The subordinated debts of a bank optimizing its liability structure as a result of deposit insurance falls. Over all, they predict that total leverage increases and equity falls with the implementation of deposit insurance. The deposits increase and the subordinated debt decrease. They claim that the total leverage ratio is determined by how these two interact 
with deposit insurance and the tax regime. They hypothesize that the account servicing of deposits is a vital part of the liability structure optimizing.

Regularity intervention is found to positively impact bank performance (Igbinosa, Sunday \& Babatunde, 2017). Using this study as a theoretical basis, this study tries to see whether the theoretical behaviour of bank optimizing its liability structure in response to deposit insurance is, in fact, backed by empirical evidence.

\section{Model}

To investigate the theory of the effect of deposit insurance on the liability structure proposed, the following model is used:

$$
\begin{aligned}
\mathrm{Y}_{i c t}=\beta_{0}+\beta_{1} & \text { Profit }_{i c t-1}+\beta_{2} \text { Tax }_{i c t-1}+\beta_{3} \text { OverHead }_{i c t-1}+\beta_{4} \text { Dividend }_{i c t-1} \\
& +\beta_{5} \text { DepositInsurance }_{i c t}+\beta_{6} \text { Ln } \text { Size }_{\text {ict }-1}+\beta_{7} \text { Liquidity }_{i c t-1} \\
& +\delta_{c} \text { CountryDummy }_{c}+\gamma_{t} \text { TimeDummy }_{t}+\varnothing_{i} \text { TypeDummy }_{t} \\
& +\beta_{8} \text { Gdp }_{c t}+\beta_{9} \text { Inflation }_{c t}+\varepsilon_{i c t}
\end{aligned}
$$

The model used is the specification of Demirgüç-Kunt and Huizinga (2004) on market discipline, along with the design feature variables used in Demirgüç-Kunt and Detragiache (2002) investigating bank stability effects because of deposit insurance. Both level and change $\mathrm{Y}_{\text {ict }}$ are used. Gropp and Heider (2010) use market and book value (1-Capital/Asset) to define leverage in their study testing capital structure theories of nonfinancial firms on banks. The dependent variables used are the leverage ratio, deposit ratio and its decomposed individual deposit type ratios, short term funding, and long-term funding. The leverage ratio is defined as the total liabilities to total assets. The total deposit to asset ratio is used to investigate whether the ratio increases. The study decomposed the deposit ratio into three different categories: Term, current and saving deposits. The term deposits are long-term deposits, which are fixed time period deposits. The current deposits are non-interest-bearing deposits. Finally, saving deposits are interestbearing deposits, which can be withdrawn whenever the depositor wants to.

The model also uses dependent variables representing the liabilities based on their maturity to investigate their behaviour in response to explicit deposit insurance. For this purpose two ratios are used: "Deposits and other Short-term funding ratio", and "Long-term liabilities ratio". Ratios are calculated with respect to total assets. The model incorporates the design features of deposit insurance pro- 
posed by Demirgüç-Kunt and Detragiache (2002). The model is estimated using pooled OLS within estimation. The cluster robust standard errors are reported to allow for heteroscedastic and correlated error terms within groups. The correlation matrix is shown in table 1 .

The Variance Inflation Factors are calculated to check for the multicollinearity issue. Table la shows the Vif for all the models estimated.

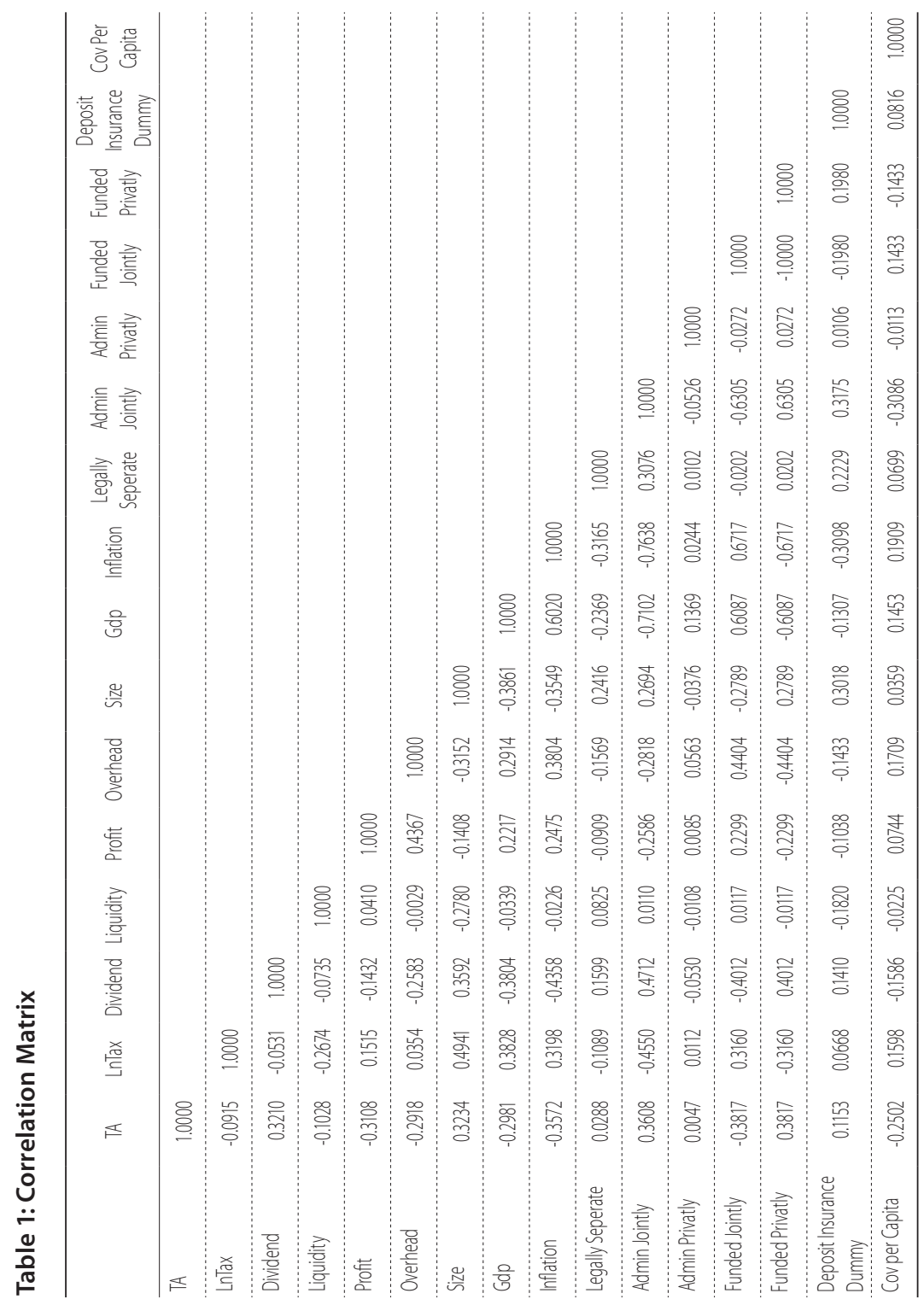


Table 1a: Variance Inflation Factors for all models tested

\begin{tabular}{lccc}
\hline Dependent Variable & Variable & $\begin{array}{c}\text { Deposit Insurance } \\
\text { Dummy }\end{array}$ & Mean VIF \\
\hline Term Deposit Ratio Change & VIF & 4.82 & 4.37 \\
\hline Term Deposit Ratio Level & VIF & 4.84 & 4.38 \\
\hline Current Deposit Ratio Change & VIF & 4.94 & 4.48 \\
\hline Current Deposit Ratio Level & VIF & 4.95 & 4.48 \\
\hline Saving Deposit Ratio Change & VIF & 4.93 & 4.38 \\
\hline Saving Deposit Ratio Level & VIF & 4.93 & 4.38 \\
\hline Non Deposit Ratio Change & VIF & 4.93 & 4.38 \\
\hline Non Deposit Ratio Level & VIF & 4.93 & 4.38 \\
\hline Short term funding Ratio Change & VIF & 4.93 & 4.38 \\
\hline Short term funding Ratio Level & VIF & 4.93 & 4.38 \\
\hline Deposit Ratio Change & VIF & 4.93 & 4.38 \\
\hline Deposit Ratio Level & VIF & VIF & 4.93 \\
\hline Leverage Ratio Change & VIF & 4.93 & 4.38 \\
\hline Leverage Ratio Level & & 4.93 & 4.38 \\
\hline
\end{tabular}

\subsection{Data}

The data is comprised of unbalanced panel of banks from 30 Asian countries with data from 2000-2012. The use of difference in the difference dependent variable reduces the effective number of years by 1 year.

The study uses information of the deposit insurance programs and its design features in Asia from the database created by Demirgüç-Kunt (2013) as part of the World Bank initiative. The deposit insurance dummy takes a value of 1 if there is explicit insurance provided in the particular country and 0 means the absence of explicit deposit insurance provided by the government. In countries with an absence of explicit deposit insurance banks may provide implicit deposit insurance to their customers.

The explicit deposit insurance program design features are based on how the system is administered, funded, organization structure and coverage that they provide. The explicit deposit insurance programs are run either as a separate legal entity or as a subsidiary of the central bank. This feature is predicted to have an influence on the policy enforcement of the scheme and have an effect on disciplining by the depositors. The model uses a 0 or 1 reference with 1 referring to the fact that the deposit insurance scheme is a separate body. 
The administration of the explicit insurance scheme is also done either privately publicly or jointly. 0 or 1 dummy are used to specify the type of administration of the scheme. The sample of Asian countries has a larger portion of countries administering the explicit deposit insurance scheme jointly. Similarly the government funds the insurance scheme privately or jointly. Binary $0-1$ value variables are used in the models that check for the effect on the liability structure.

The source of the bank specific variables is Bankscope Bureau van Dijk. Year-end annual data in dollar terms is used. Market discipline studies (Ioannidou, \& De Dreu, 2019; Nys, Tarazi \& Trinugroho, 2015; Keiko \& Masahiro, 2004; Fueda \& Konishi, 2007) are a few of the studies that investigate the market disciplining done by using lagged bank fundamentals on the dependent variables. In this paper the Demirgüç-Kunt and Huizinga (2004) model is extended to investigate the effect of explicit deposit insurance and its design on the liability structure of the bank.

Overhead is a bank's noninterest expenses to total assets. According to Demirgüç-Kunt and Huizinga (2004), it can be interpreted as a reflection of differences in the quality of service and bank product composition. It can also be interpreted as the cost efficiency measure of a bank reflecting costs that the bank incurs other than interest on its liabilities and, for this particular paper, as representing the account servicing costs that the bank incurs.

Size is the log of the total asset to GDP. ROA is used as risk measure in concurrence with the Demirgüç-Kunt and Huizinga (2004) study. The macroeconomic variables are taken from the IFS database and the World Bank data resource online. GDP is the percentage of real GDP growth. The inflation rate data is also included into the model.

\section{Main Results}

Sundaresan and Wang (2014) classify the liability structure of banks into deposit and subordinated debt, forming the total liability for simplicity. For empirical investigation, the liability is divided into total deposit liabilities to total bank assets and non-deposit liability to total bank assets ratios. The effect deposit insurance has on the total leverage is also investigated using the total liabilities to total assets ratio. 


\section{Table 2: Effect of Explicit Deposit Insurance in Asia}

The estimated model is $Y_{\mathrm{ict}}=\beta_{0}+\beta_{1}$ Profit $_{\mathrm{ict}-1}+\beta_{2}$ Tax $_{\mathrm{ict}-1}+\beta_{3}$ OverHead $_{\mathrm{ict}-\mathrm{1}}+\beta_{4}$ Dividend $_{\mathrm{ict}-1}+\beta_{5}$ DepositInsurance $_{\mathrm{ict}}+\beta_{6}$

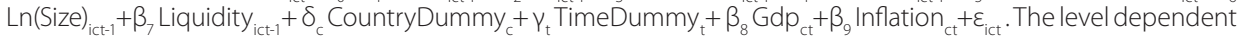
variable $Y_{\text {ict }}$ takes the form of leverage ratio which is the total liabilities to total assets, Non deposit liabilities/ Total Asset, Short term funding ratio is short term deposits and other shortterm liabilites to total asset and finally the deposit to total asset ratio. Change dependent variables are $Y_{\text {ict }}-Y_{\text {ict-1 }}$ The Profit is defined as the net income to total assets. Tax is $\log$ (Tax expenses). Overhead is the personal expense and other noninterest expense to total asset. Liquidity is the total liquid assets to total assets. The Dividend is a 0 or 1 dummy with 1 representing dividend payout year. Size is the log of total assets to total Gdp.Time country and bank type dummies are estimated but not reported in the table. Robust standard errors are reported clustered at bank level.

\begin{tabular}{|c|c|c|c|c|c|c|c|c|}
\hline & \multicolumn{2}{|c|}{ Leverage Ratio } & \multicolumn{2}{|c|}{$\begin{array}{l}\text { NonDeposit } \\
\text { to Asset }\end{array}$} & \multicolumn{2}{|c|}{$\begin{array}{c}\text { Short Term } \\
\text { Funding } \\
\text { Ratio }\end{array}$} & \multicolumn{2}{|c|}{ Deposit Ratio } \\
\hline & Level & Change & Level & Change & Level & Change & Level & Change \\
\hline \multicolumn{9}{|l|}{$\begin{array}{l}\text { Bank Specific } \\
\text { Variables }\end{array}$} \\
\hline \multirow{2}{*}{ Size } & $0.0112^{* * *}$ & -0.0007 & -0.0011 & -0.0013 & $0.0087^{* * *}$ & -0.0013 & $0.0123^{* * *}$ & 0.0005 \\
\hline & $(0.0013)$ & $(0.0005)$ & $(0.0024)$ & $(0.0012)$ & $(0.0019)$ & $(0.0009)$ & $(0.0029)$ & $(0.0013)$ \\
\hline \multirow{2}{*}{ Profit } & $-1.8287^{* * *}$ & 0.0744 & 0.2016 & -0.0046 & $-1.8822^{* * *}$ & 0.1903 & $-2.0303^{* * *}$ & 0.0791 \\
\hline & $(0.2254)$ & $(0.0801)$ & $(0.3763)$ & $(0.1126)$ & $(0.3748)$ & $(0.1448)$ & $(0.4819)$ & $(0.1405)$ \\
\hline \multirow{2}{*}{$\operatorname{Tax}$} & $-0.0040^{* * *}$ & $-0.0008^{* *}$ & $0.0046^{* *}$ & 0.0011 & $-0.0070^{* * *}$ & $-0.0012^{* *}$ & $-0.0086^{* * *}$ & $-0.0019^{*}$ \\
\hline & $(0.0008)$ & $(0.0003)$ & $(0.0018)$ & $(0.0010)$ & $(0.0014)$ & $(0.0006)$ & $(0.0020)$ & $(0.0010)$ \\
\hline \multirow{2}{*}{ Dividend } & $0.0101^{* * *}$ & 0.0003 & $-0.0136^{* *}$ & 0.0002 & $0.0167^{* *}$ & 0.0012 & $0.0237^{* *}$ & 0.0001 \\
\hline & $(0.0030)$ & $(0.0010)$ & $(0.0068)$ & $(0.0021)$ & $(0.0051)$ & $(0.0019)$ & $(0.0079)$ & $(0.0022)$ \\
\hline \multirow{2}{*}{ Liquidity } & 0.0099 & -0.0045 & 0.0063 & 0.0019 & 0.0164 & $-0.0157^{* *}$ & 0.0036 & -0.0064 \\
\hline & $(0.0134)$ & $(0.0045)$ & $(0.0342)$ & $(0.0082)$ & $(0.0218)$ & $(0.0077)$ & $(0.0363)$ & $(0.0083)$ \\
\hline \multirow{2}{*}{ Overhead } & 0.0919 & $0.1864^{*}$ & 0.3427 & 0.1468 & -0.2525 & 0.1333 & -0.2508 & 0.0397 \\
\hline & $(0.1368)$ & $(0.0965)$ & -0.4741 & $(0.0892)$ & $(0.4294)$ & $(0.1529)$ & $(0.5566)$ & $(0.1503)$ \\
\hline \multirow{2}{*}{$\begin{array}{l}\text { Deposit Insurance } \\
\text { Dummy }\end{array}$} & $-0.0122^{*}$ & -0.0007 & -0.0166 & 0.0057 & 0.0044 & $-0.0118^{* *}$ & 0.0044 & -0.0064 \\
\hline & $(0.0063)$ & $(0.0038)$ & $(0.0136)$ & $(0.0058)$ & $(0.0121)$ & $(0.0052)$ & $(0.0158)$ & $(0.0069)$ \\
\hline \multicolumn{9}{|l|}{$\begin{array}{l}\text { Macroecomic } \\
\text { Variables }\end{array}$} \\
\hline \multirow{2}{*}{ GDP Growth } & -0.0166 & -0.0009 & $-0.2483^{* *}$ & $-0.1868^{*}$ & 0.0698 & -0.0749 & $0.2316^{* *}$ & $0.1858^{*}$ \\
\hline & $(0.0454)$ & $(0.0309)$ & $(0.1007)$ & $(0.0976)$ & $(0.0880)$ & $(0.0658)$ & $(0.1077)$ & $(0.1018)$ \\
\hline \multirow{2}{*}{ Inflation } & $-0.1272^{* *}$ & 0.0004 & 0.0111 & -0.0493 & $-0.2774^{* * *}$ & -0.0045 & -0.1383 & 0.0497 \\
\hline & $(0.0395)$ & $(0.0250)$ & $(0.0945)$ & $(0.0654)$ & $(0.0807)$ & $(0.0531)$ & $(0.1033)$ & $(0.0640)$ \\
\hline \multirow{2}{*}{ Constant } & $0.7792^{* * *}$ & $0.0215^{* *}$ & -0.0201 & 0.0004 & $0.8484^{* * *}$ & $0.0481^{* *}$ & $0.7993^{* * *}$ & 0.0211 \\
\hline & $(0.0238)$ & $(0.0099)$ & $(0.0492)$ & $(0.0190)$ & $(0.0401)$ & $(0.0154)$ & $(0.0598)$ & $(0.0200)$ \\
\hline R-squared & 0.493 & 0.052 & 0.608 & 0.036 & 0.620 & 0.060 & 0.652 & 0.037 \\
\hline Adj. R-squared & 0.487 & 0.041 & 0.603 & 0.025 & 0.615 & 0.049 & 0.648 & 0.026 \\
\hline No. of 0 bs & 4308 & 4308 & 4308 & 4308 & 4308 & 4308 & 4308 & 4308 \\
\hline
\end{tabular}

${ }^{*} p<.1,{ }^{* *} p<.05,{ }^{* * *} p<.001$ 
Table 2 shows the results of the estimation of the level and \%age change dependent variable ratios. Consistent with the previous literature the growth dependent variable models seem to exhibit a low fit. (Demirgüç-Kunt, \& Huizinga, 2004; Park, 1995; Murata \& Hori, 2004) all use percentage of deposits as dependent variables and exhibit low R-squared values. The level dependent variable models, however, have a good fit. The first model uses the leverage ratio (Total Liabilities/ Total Assets) as the dependent variable. The next models are the decomposition of the leverage into deposit ratios and non-deposit ratios and short-term funding ratio. Short term funding includes the customer deposits and other short-term funding according to the Bankscope database.

Sundaresan and Wang (2014) predict an increase in the level of leverage ratio maintained by banks as a result of explicit deposit insurance. The change leverage model uses the difference term for Total Liabilities/Total Assets as the dependent variable. It represents how the ratios growth rate changes. The paper does not find any significant evidence of the effect of explicit deposit insurance on how the leverage grows or shrinks. The deposit insurance dummy has a negative significant sign indicating a decrease of $1.22 \%$ after the implementation of the deposit insurance scheme. Although the result is counterintuitive, some studies indicate an increase in moral hazard as secured deposits induce banks into risky lending. An increase in risky assets would cause the bank to readjust according to the CAR requirements and the banks would have an increase its equity. This would result in a decrease in the leverage ratio. The paper finds that the change in leverage is dependent on the deposits and non-deposits liabilities.

Decomposing the total liability into its determining components as Sundaresan and Wang (2014) specify evidences that deposit insurance results in the nondeposit liabilities ratio to fall and the deposits ratio to increase on the level. Surprisingly enough, both of the ratios are insignificant. Demirgüç-Kunt and Huzinger (2004) also find no evidence of growth in deposits as evidence of market disciplining. Since most studies focus on total customer deposits to access market discipline, the paper used the same ratio. It finds that in order to capture the effect of explicit deposit insurance it is better to see the effect on individual deposits rather than all customer deposits as a whole. Ioannidou and De Dreu (2019) find that evidence of reduced monitoring and discipline of bank risk in specifically large depositors who are already active in imposing discipline.

Sundaresan and Wang (2014) predict that in lower tax rate regimes the banks use lower leverage since the decrease in subordinated debt is larger than an increase in deposits. Empirical evidence in Asian banks, however, points to the contrary. 
The tax expense proxies the tax rate in the models. The study finds strong and significant decrease in the leverage as the tax rate increases.

As tax expenses increase, banks increase their subordinated debt in order to take advantage of the tax advantage the debt is accompanied with. The positive sign of the non-deposit liabilities to total assets ratio because of tax expense and the negative impact of increase taxes that the bank faces can be seen in the preceding models in Table 1. The effect of tax expense causes a higher level of decrease in deposits than an increase in subordinated debt, which ultimately forms the overall direction of the change in leverage. In Asian countries, the deposit ratio level decreases more than the increase in the non-deposit liabilities ratio causing the increasing tax rates to have a negative effect on the banks' leverage position.

Sundaresan and Wang (2014) find that the gains from servicing deposits, which they call the account service income, is detrimental to bank's liability structure.

In the model, the independent variable overhead is defined as personal expenses and other non-interest expenses over total assets. Demirgüç-Kunt and Huizinga (2004) describe it as an indicator of servicing quality and differences in product mix. The overhead has a positive insignificant effect on the leverage ratio. The growth rate of leverage, however, is affected at a $10 \%$ significant level. Overall, we find that overhead expenses have no significant effect on a bank's liability structure.

This study does not find any evidence of deposit growth or a change in the level of deposit ratio that banks maintain using total customer deposits. Other studies on the impact of explicit deposit insurances also find similar results. The loss in individual bank profitability reported in literature can be attributed to the fact that this policy does not result in any growth in deposits.

In order to investigate this further, the deposit ratio is decomposed into saving deposits, term deposits, and current deposits. The sample of Asian countries has, on average, $63 \%$ of term deposits, $13 \%$ of savings, and $24 \%$ of current deposits to total customer deposits. 


\section{Table 3: Decomposition of Total Customer Deposit Ratio}

The estimated model is $Y_{\mathrm{ict}}=\beta 0+\beta 1$ Profit ${ }_{\mathrm{ict}-1}+\beta 2$ Taxict $-1+\beta 3$ OverHeadict- $1+\beta 4$ Dividendict $-1+\beta 5$ Depositlnsuranceict+ $\beta 6$ Ln(Size)ict-1+ $\beta 7$ Liquidityict- $1+\delta c$ CountryDummyc $+\gamma t$ TimeDummyt+ $\beta 8$ Gdpct+ $\beta 9$ Inflationct+eict. The dependent variable Yict takes the form of Term deposits/TotalAsset, Saving deposits/ TotalAsset and Current deposits/TotalAsset. The Profit is defined as the net income to total assets. Tax is log(Tax expenses). Overhead is the personal expense and other noninterest expense to total asset.Liquidity is the total liquid assets to total assets. The Dividend is a 0 or 1 dummy with 1 representing dividend payout year. Size is the log of total assets to total Gdp.Time country and bank type dummies are estimated but not reported in the table. Robust standard errors are reported clustered at bank level.

\begin{tabular}{|c|c|c|c|c|c|c|}
\hline & \multicolumn{2}{|c|}{$\begin{array}{l}\text { Term Deposits/ } \\
\text { Total Asset }\end{array}$} & \multicolumn{2}{|c|}{$\begin{array}{l}\text { Saving Deposits/ } \\
\text { Total Asset }\end{array}$} & \multicolumn{2}{|c|}{$\begin{array}{c}\text { Current Deposits/ } \\
\text { Total Asset }\end{array}$} \\
\hline & Level & Change & Level & Change & Level & Change \\
\hline \multicolumn{7}{|l|}{$\begin{array}{l}\text { Bank Specific } \\
\text { Variables }\end{array}$} \\
\hline \multirow{2}{*}{ Profit } & $-2.3062^{* * *}$ & $0.6105^{* * *}$ & -0.0296 & $-0.5021^{* * *}$ & 0.3385 & -0.0829 \\
\hline & $(0.6407)$ & $(0.1533)$ & $(0.3652)$ & $(0.1265)$ & $(0.2898)$ & $(0.1097)$ \\
\hline \multirow{2}{*}{ Tax } & $-0.0126^{* * *}$ & -0.0009 & 0.0024 & -0.0007 & 0.0016 & -0.0006 \\
\hline & $(0.0029)$ & $(0.0010)$ & $(0.0020)$ & $(0.0007)$ & $(0.0018)$ & $(0.0005)$ \\
\hline \multirow{2}{*}{ Dividend } & 0.0115 & 0.0006 & 0.0058 & 0.0017 & -0.0001 & -0.0009 \\
\hline & $(0.0095)$ & $(0.0022)$ & $(0.0081)$ & $(0.0021)$ & $(0.0055)$ & $(0.0015)$ \\
\hline \multirow{2}{*}{ Liquidity } & $-0.2140^{* * *}$ & -0.0113 & $0.0839^{* *}$ & 0.0065 & $0.1381^{* * *}$ & -0.0027 \\
\hline & $(0.0404)$ & $(0.0089)$ & $(0.0316)$ & $(0.0072)$ & $(0.0313)$ & $(0.0068)$ \\
\hline \multirow{2}{*}{ Overhead } & $-1.2371^{*}$ & 0.0670 & 0.5286 & $-0.1163^{*}$ & 0.4918 & 0.1314 \\
\hline & $(0.6817)$ & $(0.0879)$ & $(0.3302)$ & $(0.0680)$ & $(0.3192)$ & $(0.1238)$ \\
\hline \multirow{2}{*}{ Size } & $-0.0121^{* *}$ & -0.0018 & $0.0129^{* * *}$ & $0.0014^{*}$ & $0.0108^{* * *}$ & 0.0010 \\
\hline & $(0.0038)$ & $(0.0012)$ & $(0.0024)$ & (0.0008) & $(0.0024)$ & $(0.0007)$ \\
\hline \multirow{2}{*}{$\begin{array}{l}\text { Deposit } \\
\text { Insurance } \\
\text { Dummy }\end{array}$} & $0.0484^{* *}$ & 0.0017 & $-0.0235^{* *}$ & $-0.0085^{* *}$ & $-0.0206^{* *}$ & -0.0004 \\
\hline & $(0.0189)$ & $(0.0067)$ & $(0.0116)$ & $(0.0034)$ & $(0.0098)$ & $(0.0042)$ \\
\hline \multicolumn{7}{|l|}{$\begin{array}{l}\text { Macroeconomic } \\
\text { Variables }\end{array}$} \\
\hline \multirow{2}{*}{ GDP Growth } & 0.1504 & $0.4629^{* * *}$ & 0.1718 & $-0.2109^{* *}$ & 0.0292 & -0.0600 \\
\hline & $(0.2449)$ & $(0.1212)$ & $(0.1197)$ & $(0.0663)$ & $(0.1414)$ & $(0.0486)$ \\
\hline \multirow{2}{*}{ Inflation } & $0.2804^{* *}$ & 0.0956 & $-0.5054^{* * *}$ & -0.0707 & 0.0087 & -0.0084 \\
\hline & $(0.1154)$ & $(0.0642)$ & $(0.1121)$ & $(0.0529)$ & $(0.0630)$ & $(0.0287)$ \\
\hline \multirow{2}{*}{ Constant } & $1.1146^{* * *}$ & 0.0016 & $-0.2911^{* * *}$ & -0.0062 & -0.0047 & $0.0229^{*}$ \\
\hline & $(0.1026)$ & $(0.0197)$ & $(0.0721)$ & $(0.0124)$ & $(0.0512)$ & $(0.0130)$ \\
\hline R-squared & 0.677 & 0.093 & 0.708 & 0.040 & 0.569 & 0.147 \\
\hline Adj. R-squared & 0.673 & 0.082 & 0.705 & 0.029 & 0.564 & 0.137 \\
\hline No. of Obs & 4278 & 4272 & 4308 & 4308 & 4275 & 4270 \\
\hline
\end{tabular}

${ }^{*} p<.1,{ }^{* *} p<.05,{ }^{* * *} p<.001$ 
The results from table 3 reveal an evident shift from saving and current to long term fixed term deposits. Safety nets are theorized to reduce the chances of bank runs. The reduction in current deposits would reduce the likelihood of a bankruptcy. As a trade-off to reduced exposure to bank-runs, the provider of liquidity of function of the banks would also be adversely affected. These findings are consistent with findings in other studies (Diamond \& Dybvig, 1983; Goldstein \& Pauzner, 2005). The saving deposits reveal a significant decrease in their saving deposits growth at 5\% significance level. The decomposition of total customer deposits results in evidence that the previous cross-country studies have not revealed. The term deposits ratio increases by almost $4.84 \%$ significantly at $5 \%$ level. This shift is countered by a decrease of $2.35 \%$ in the saving deposits and $2.06 \%$ decrease in the current deposits ratio. The total increase is evident from the total deposit increase, as seen in table 2. The banks' overall response to explicit deposit insurance if the total customer deposits are used in the market discipline analysis is determined by the composition of deposits.

Liquidity has a positive relationship with both the current and saving deposits. Since term deposits are fixed over a longer period, the liquidity ratio has a negative relationship with it. The dividend independent variable takes the value of 1 if the dividend gets paid on a particular day. Unlike the Gropp \& Heider (2010) findings, the paper does not find any significant effect on the liability and leverage ratios. Size is the total bank assets and we find that larger banks have a larger leverage ratio. Bank size also has a positive effect on the bank's deposit ratio. 


\subsection{Deposit Insurance Design Effect}

Different countries have experimented with how the insurance scheme is implemented. Demirgüç-Kunt and Detragiache (2002) find that the deposit design features have a significant effect on bank stability. To investigate how the design affects the bank's liability and leverage ratio, this study checks for the effect of coverage, administration, ownership, and funding on the individual models.

Coverage is about the magnitude rather than the presence of the safety net. It measures maximum amount of deposits the scheme insures. The models use the log of per capital deposits covered. Rather than studying the effect of the introduction of the scheme the amount of the cover is found to have a separate effect. The leverage ratio has a positive relationship with the amount of coverage. Increasing the amount covered increases the deposit ratio of the bank at 5\% significance in the level dependent variable model. The non-deposit liabilities to total assets also exhibit a decrease at $10 \%$ level. The short-term funds ratio exhibits a positive but insignificant increase.

Deposit insurance has been referred to as a double-edged sword. The paper finds that the application of deposit insurance has a negative effect on leverage but if the coverage were increased it would result in the leverage increasing. Incorrectly set coverage would lead to the dreaded moral hazard problem, leading to a decrease in the capital to assets ratio if a strong regulation enforcement structure is not in place. The effect of coverage per capita on the level of decomposed saving and term deposit ratios is consistent with the total deposit ratio model findings. The result, however, is not significant for any inference to be made. 


\section{Table 4: Design Feature Coverage Per Capita}

The estimated model is Yict $=\beta 0+\beta 1$ Profitict $-1+\beta 2$ Taxict- $1+\beta 3$ OverHeadict- $1+\beta 4$ Dividendict $-1+\beta 5$ $\operatorname{Ln}($ CovPerCapita)ict $+\beta 6$ Ln(Size)ict- $1+\beta 7$ Liquidityict- $1+\delta c$ CountryDummyc $+\gamma t$ TimeDummyt+ $\beta 8$ Gdpct $+\beta 9$ Inflationct+eict. The level dependent variable Yict takes the form of leverage ratio which is the total liabilities to total assets, Non deposit liabilities/ Total Asset, Short term funding ratio is short term deposits and other shortterm liabilites to total asset and finally the deposit to total asset ratio. The Profit is defined as the net income to total assets. Tax is $\log (\operatorname{Tax}$ expenses). Overhead is the personal expense and other noninterest expense to total asset.Liquidity is the total liquid assets to total assets. The Dividend is a 0 or 1 dummy with 1 representing dividend payout year. Size is the log of total assets to total Gdp. Ln(CovPerCapita) is the log of coverage per capita.The sample of banks are those using explicit deposit insurance. Robust standard errors are reported clustered at bank level.

\begin{tabular}{|c|c|c|c|c|c|c|}
\hline & $\begin{array}{l}\text { Leverage } \\
\text { Ratio }\end{array}$ & $\begin{array}{l}\text { Non Deposit } \\
\text { Ratio }\end{array}$ & $\begin{array}{c}\text { Short Term } \\
\text { Funding Ratio }\end{array}$ & $\begin{array}{l}\text { Deposit } \\
\text { Ratio }\end{array}$ & $\begin{array}{c}\text { Saving } \\
\text { Deposit } \\
\text { Ratio }\end{array}$ & $\begin{array}{l}\text { Term } \\
\text { Deposit } \\
\text { Ratio }\end{array}$ \\
\hline & Level & Level & Level & Level & Level & Level \\
\hline \multicolumn{7}{|l|}{$\begin{array}{l}\text { Bank Specific } \\
\text { Variables }\end{array}$} \\
\hline \multirow{2}{*}{ Size } & $0.0126^{* * *}$ & 0.0004 & $0.0108^{* * *}$ & $0.0122^{* * *}$ & $0.0107^{* * *}$ & $-0.0118^{* *}$ \\
\hline & $(0.0016)$ & $(0.0025)$ & $(0.0023)$ & $(0.0034)$ & $(0.0023)$ & $(0.0044)$ \\
\hline \multirow{2}{*}{ Profit } & $-1.9349^{* * *}$ & 0.5279 & $-2.1704^{* * *}$ & $-2.4628^{* * *}$ & 0.0562 & $-2.7393^{* * *}$ \\
\hline & $(0.2689)$ & $(0.3901)$ & $(0.3621)$ & $(0.4762)$ & $(0.4159)$ & $(0.7017)$ \\
\hline \multirow{2}{*}{ Tax } & $-0.0054^{* * *}$ & $0.0043^{* *}$ & $-0.0094^{* * *}$ & $-0.0097^{* * *}$ & $0.0051^{* *}$ & $-0.0142^{* * *}$ \\
\hline & $(0.0009)$ & $(0.0019)$ & $(0.0016)$ & $(0.0023)$ & $(0.0019)$ & $(0.0034)$ \\
\hline \multirow{2}{*}{ Dividend } & $0.0099^{* *}$ & $-0.0133^{*}$ & $0.0169^{* *}$ & $0.0232^{* *}$ & 0.0042 & $0.0190^{*}$ \\
\hline & $(0.0035)$ & $(0.0080)$ & $(0.0057)$ & $(0.0091)$ & $(0.0090)$ & $(0.0108)$ \\
\hline \multirow{2}{*}{ Liquidity } & 0.0119 & 0.0143 & 0.0081 & -0.0024 & $0.0770^{* *}$ & $-0.2155^{* * *}$ \\
\hline & $(0.0135)$ & $(0.0301)$ & $(0.0223)$ & $(0.0314)$ & $(0.0276)$ & $(0.0465)$ \\
\hline \multirow{2}{*}{ Overhead } & 0.2374 & 0.7307 & -0.3784 & -0.4933 & 0.5214 & -1.3413 \\
\hline & $(0.1474)$ & $(0.5178)$ & $(0.4752)$ & $(0.6201)$ & $(0.3759)$ & $(0.8295)$ \\
\hline \multicolumn{7}{|l|}{ Insurance Design } \\
\hline \multirow{2}{*}{ Ln(CovPerCapita) } & $0.0104^{*}$ & $-0.0211^{*}$ & 0.0163 & $0.0314^{* *}$ & 0.0012 & 0.0218 \\
\hline & $(0.0056)$ & $(0.0127)$ & $(0.0108)$ & $(0.0156)$ & $(0.0115)$ & $(0.0162)$ \\
\hline \multicolumn{7}{|l|}{ Macroeconomic } \\
\hline \multirow{2}{*}{ Gdp Growth } & -0.0755 & $-0.2667^{* *}$ & -0.1252 & 0.1912 & $-0.2388^{* *}$ & $0.5175^{* *}$ \\
\hline & $(0.0599)$ & (0.1309) & $(0.0952)$ & $(0.1407)$ & $(0.1091)$ & $(0.1696)$ \\
\hline \multirow{2}{*}{ Inflation } & $-0.1175^{* *}$ & 0.0260 & -0.1632 & -0.1435 & $-0.3373^{* *}$ & $0.3109^{*}$ \\
\hline & $(0.0523)$ & $(0.1253)$ & $(0.1010)$ & $(0.1432)$ & $(0.1651)$ & $(0.1614)$ \\
\hline \multirow{2}{*}{ Constant } & $0.6901^{* * *}$ & 0.0426 & $0.7492^{* * *}$ & $0.6475^{* * *}$ & $-0.3064^{* *}$ & $1.0563^{* * *}$ \\
\hline & $(0.0365)$ & $(0.0786)$ & $(0.0606)$ & $(0.0914)$ & (0.0995) & $(0.1474)$ \\
\hline R-squared & 0.492 & 0.636 & 0.609 & 0.678 & 0.674 & 0.606 \\
\hline Adj. R-squared & 0.486 & 0.631 & 0.605 & 0.674 & 0.670 & 0.601 \\
\hline No. of Obs & 3741 & 3741 & 3741 & 3741 & 3741 & 3725 \\
\hline
\end{tabular}

${ }^{*} p<.1,{ }^{* *} p<.05,{ }^{* * *} p<.001$ 
The deposit insurance scheme is either run as a separate legal entity/corporation or by central bank/regulatory authority. The deposit insurance dummy alone captures the effect of the insurance scheme if run as an entity controlled by the central bank or the regulatory authority. The legally separate dummy carries a value of 1 if it is a separate entity free from the influence of the central bank and regulatory bodies; otherwise, the value is 0 . It is interacted with the deposit insurance dummy. The interaction term is used to capture the effect of how the effectiveness of the deposit insurance scheme varies with the ownership of the deposit insurance scheme. The coefficient captures the use of deposit insurance effect of a legally separate insuring body.

If legal separate entities run the safety net programs, they have a significantly lower effect on the liability ratios relative to programs run by central banks or regulatory bodies. Schemes run by the legally separate bodies reduce the leverage ratio rather than increasing it. This effect, however, is not significant. 


\section{Table 5: Design Feature Ownership}

The estimated model is Yict $=\beta 0+\beta 1$ Profitict- $1+\beta 2$ Taxict $1+\beta 3$ OverHeadict- $1+\beta 4$ Dividendict $-1+\beta 5$ DepositInsurancexLegallySeperateict $+\beta 6 \operatorname{Ln}($ Size)ict $1+\beta 7$ Liquidityict- $1+\delta c$ CountryDummyc $+\gamma t$ TimeDummyt +

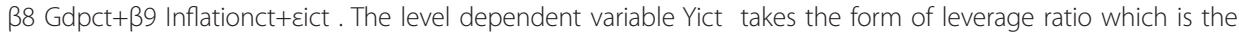
total liabilities to total assets, Non deposit liabilities/ Total Asset, Short term funding ratio is short term deposits and other shortterm liabilites to total asset and finally the deposit to total asset ratio. Change dependent variables are Yict-Yict-1 The Profit is defined as the net income to total assets. Tax is $\log ($ Tax expenses). Overhead is the personal expense and other noninterest expense to total asset. Liquidity is the total liquid assets to total assets. The Dividend is a 0 or 1 dummy with 1 representing dividend payout year. Size is the log of total assets to total Gdp. The legally seperate dummy is also interacted with the deposit insurance dummy. The reference dummy is through government ownership. The sample of banks are those using explicit deposit insurance. Robust standard errors are reported clustered at bank level.

\begin{tabular}{|c|c|c|c|c|c|c|}
\hline & $\begin{array}{l}\text { Leverage } \\
\text { Ratio }\end{array}$ & $\begin{array}{l}\text { Non Deposit } \\
\text { Ratio }\end{array}$ & $\begin{array}{l}\text { Short Term } \\
\text { Funding Ratio }\end{array}$ & $\begin{array}{l}\text { Deposit } \\
\text { Ratio }\end{array}$ & $\begin{array}{l}\text { Saving } \\
\text { Deposit } \\
\text { Ratio }\end{array}$ & $\begin{array}{l}\text { Term } \\
\text { Deposit } \\
\text { Ratio }\end{array}$ \\
\hline & Level & Level & Level & Level & Level & Level \\
\hline \multicolumn{7}{|l|}{$\begin{array}{l}\text { Bank Specific } \\
\text { Variables }\end{array}$} \\
\hline \multirow{2}{*}{ Size } & $0.0126^{* * *}$ & -0.0002 & $0.0104^{* * *}$ & $0.0128^{* * *}$ & $0.0135^{* * *}$ & $-0.0128^{* *}$ \\
\hline & $(0.0014)$ & $(0.0027)$ & $(0.0023)$ & $(0.0033)$ & $(0.0023)$ & $(0.0043)$ \\
\hline \multirow{2}{*}{ Profit } & $-1.9041^{* *}$ & 0.2321 & $-2.0033^{* * *}$ & $-2.1362^{* * *}$ & 0.1929 & $-2.5694^{* * *}$ \\
\hline & $(0.2496)$ & $(0.4189)$ & $(0.4121)$ & $(0.5301)$ & $(0.3916)$ & $(0.6936)$ \\
\hline \multirow{2}{*}{ Tax } & $-0.0051^{* * *}$ & $0.0040^{* *}$ & $-0.0084^{* * *}$ & $-0.0092^{* * *}$ & $0.0046^{* *}$ & $-0.0139^{* * *}$ \\
\hline & $(0.0009)$ & $(0.0020)$ & $(0.0016)$ & $(0.0023)$ & $(0.0017)$ & $(0.0032)$ \\
\hline \multirow{2}{*}{ Dividend } & $0.0104^{* *}$ & $-0.0143^{*}$ & $0.0185^{* *}$ & $0.0247^{* *}$ & 0.0082 & $0.0178^{*}$ \\
\hline & $(0.0034)$ & $(0.0078)$ & $(0.0057)$ & $(0.0090)$ & $(0.0085)$ & $(0.0106)$ \\
\hline \multirow{2}{*}{ Liquidity } & 0.0156 & -0.0101 & 0.0218 & 0.0257 & $0.0986^{* * *}$ & $-0.2196^{* * *}$ \\
\hline & $(0.0141)$ & $(0.0322)$ & $(0.0230)$ & $(0.0333)$ & $(0.0269)$ & $(0.0435)$ \\
\hline \multirow{2}{*}{ Overhead } & 0.1811 & 0.5056 & -0.2046 & -0.3245 & $0.6878^{*}$ & $-1.2573^{*}$ \\
\hline & $(0.1513)$ & $(0.5089)$ & $(0.4777)$ & $(0.6067)$ & $(0.3616)$ & $(0.7591)$ \\
\hline \multicolumn{7}{|l|}{ Insurance Design } \\
\hline \multirow{2}{*}{ DI Dummy } & 0.0007 & $-0.0928^{* *}$ & $0.1297^{* * *}$ & $0.0935^{* *}$ & -0.0089 & $0.0811^{* *}$ \\
\hline & $(0.0088)$ & $(0.0452)$ & $(0.0272)$ & $(0.0436)$ & $(0.0255)$ & $(0.0384)$ \\
\hline \multirow{2}{*}{$\begin{array}{l}\text { Legally Seperate x } \\
\text { DI Dummy }\end{array}$} & -0.0161 & $0.0852^{*}$ & $-0.1434^{* * *}$ & $-0.1012^{* *}$ & -0.0232 & -0.0348 \\
\hline & $(0.0119)$ & $(0.0486)$ & $(0.0307)$ & $(0.0479)$ & $(0.0280)$ & $(0.0446)$ \\
\hline \multicolumn{7}{|l|}{ Macroeconomic } \\
\hline \multirow{2}{*}{ Gdp Growth } & -0.0568 & $-0.2928^{* *}$ & 0.0458 & $0.2360^{* *}$ & -0.0721 & 0.2601 \\
\hline & $(0.0498)$ & $(0.1060)$ & $(0.0873)$ & $(0.1103)$ & $(0.1485)$ & $(0.3048)$ \\
\hline \multirow{2}{*}{ Inflation } & $-0.1239^{* *}$ & -0.0253 & $-0.2152^{* *}$ & -0.0986 & $-0.3342^{* *}$ & $0.2924^{* *}$ \\
\hline & $(0.0458)$ & $(0.1096)$ & $(0.0945)$ & $(0.1247)$ & $(0.1274)$ & $(0.1377)$ \\
\hline \multirow{2}{*}{ Constant } & $0.7614^{* * *}$ & -0.0427 & $0.8419^{* * *}$ & $0.8041^{* * *}$ & $-0.3314^{* * *}$ & $1.1459^{* * *}$ \\
\hline & $(0.0251)$ & $(0.0524)$ & $(0.0435)$ & $(0.0639)$ & $(0.0733)$ & $(0.1096)$ \\
\hline R-squared & 0.494 & 0.623 & 0.620 & 0.668 & 0.689 & 0.616 \\
\hline Adj. R-squared & 0.488 & 0.618 & 0.616 & 0.665 & 0.686 & 0.612 \\
\hline No. of Obs & 3967 & 3967 & 3967 & 3967 & 3967 & 3950 \\
\hline
\end{tabular}

${ }^{*} \mathrm{p}<.1,{ }^{* *} \mathrm{p}<.05,{ }^{* * *} \mathrm{p}<.001$ (DI Dummy is deposit Insurance Dummy) 
A similar effect can be seen by their effect on the non-deposit ratio. Legally separate deposit insurers have lower effect on the non-deposit ratio, significantly at $10 \%$ level. The deposit ratios exhibit a positive effect of government and a regulatory owned insurance program results in a significant increase in the deposit ratio. This is derived from the confidence of the depositors on the insuring body. The interaction term carries a significant negative effect and points to an overall negative effect if the explicit deposit insurance is implemented by legally separate bodies. Decomposing the total customer deposits into term and saving deposit ratios reveals a similar effect but at a lower significance level.

Globally, there are three choices when deciding the funding choice of explicit deposit insurance: government funded, privately funded, and jointly funded. The majority of Asian countries that have adopted the explicit deposit insurance have chosen schemes that are funded jointly. Privately funded schemes are used by fewer countries, whereas government funding is not used in Asia. The effect of funding choice on the leverage ratio and the liability ratios is shown in Table 6. The interaction term is used by interacting jointly funded dummy with the deposit insurance $0-1$ dummy. The interaction term is interpreted as the effect of using joint funding rather than privately funded programs. 


\section{Table 6: Design Feature Funding}

The estimated model is Yict $=\beta 0+\beta 1$ Profitict- $1+\beta 2$ Taxict $1+\beta 3$ OverHeadict $-1+\beta 4$ Dividendict- $1+\beta 5$ Depositlns urancexJointlyFundedict $+\beta 6$ DepositInsuranceict $+\beta 7 \operatorname{Ln}($ Size)ict- $1+\beta 8$ Liquidityict- $1+\delta c$ CountryDummyc $+\gamma t$

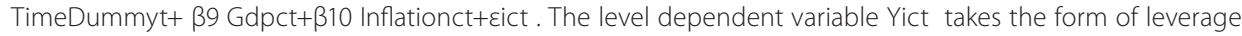
ratio which is the total liabilities to total assets, Non deposit liabilities/ Total Asset, Short term funding ratio is short term deposits and other shortterm liabilites to total asset and finally the deposit to total asset ratio and its decomposed types. The Profit is defined as the net income to total assets. Tax is $\log$ (Tax expenses). Overhead is the personal expense and other noninterest expense to total asset.Liquidity is the total liquid assets to total assets. The Dividend is a 0 or 1 dummy with 1 representing dividend payout year. Size is the log of total assets to total Gdp. The JointlyFunded dummy is interacted with the deposit insurance dummy. The reference dummy is through government funding. The sample of banks are those using explicit deposit insurance. Robust standard errors are reported clustered at bank level.

\begin{tabular}{|c|c|c|c|c|c|c|}
\hline & $\begin{array}{l}\text { Leverage } \\
\text { Ratio }\end{array}$ & $\begin{array}{l}\text { Non Deposit } \\
\text { Ratio }\end{array}$ & $\begin{array}{l}\text { Short Term } \\
\text { Funding Ratio }\end{array}$ & $\begin{array}{l}\text { Deposit } \\
\text { Ratio }\end{array}$ & $\begin{array}{c}\text { Saving } \\
\text { Deposit } \\
\text { Ratio }\end{array}$ & $\begin{array}{l}\text { Term } \\
\text { Deposit } \\
\text { Ratio }\end{array}$ \\
\hline & Level & Level & Level & Level & Level & Level \\
\hline \multicolumn{7}{|l|}{$\begin{array}{l}\text { Bank Specific } \\
\text { Variables }\end{array}$} \\
\hline \multirow{2}{*}{ Size } & $0.0123^{* * *}$ & 0.0005 & $0.0091^{* * *}$ & $0.0118^{* * *}$ & $0.0131^{* * *}$ & $-0.0131^{* *}$ \\
\hline & $(0.0014)$ & $(0.0027)$ & $(0.0022)$ & $(0.0033)$ & $(0.0023)$ & $(0.0043)$ \\
\hline \multirow{2}{*}{ Profit } & $-1.9056^{* * *}$ & 0.2277 & $-1.9989 * * *$ & $-2.1333^{* * *}$ & 0.1899 & $-2.5667^{* * *}$ \\
\hline & $(0.2469)$ & $(0.4190)$ & $(0.4067)$ & $(0.5269)$ & $(0.3926)$ & $(0.6923)$ \\
\hline \multirow{2}{*}{$\operatorname{Tax}$} & $-0.0050^{* * *}$ & $0.0037^{*}$ & $-0.0078^{* * *}$ & $-0.0087^{* * *}$ & $0.0049^{* *}$ & $-0.0138^{* * *}$ \\
\hline & $(0.0009)$ & $(0.0020)$ & $(0.0016)$ & $(0.0023)$ & $(0.0018)$ & $(0.0032)$ \\
\hline \multirow{2}{*}{ Dividend } & $0.0104^{* *}$ & $-0.0147^{*}$ & $0.0190^{* * *}$ & $0.0251^{* *}$ & 0.0082 & $0.0180^{*}$ \\
\hline & $(0.0034)$ & $(0.0078)$ & $(0.0057)$ & $(0.0090)$ & $(0.0085)$ & $(0.0106)$ \\
\hline \multirow{2}{*}{ Liquidity } & 0.0168 & -0.0076 & 0.0192 & 0.0244 & $0.1005^{* * *}$ & $-0.2203^{* * *}$ \\
\hline & $(0.0138)$ & $(0.0326)$ & $(0.0229)$ & $(0.0337)$ & $(0.0269)$ & $(0.0440)$ \\
\hline \multirow{2}{*}{ Overhead } & 0.1695 & 0.5294 & -0.2515 & -0.3599 & $0.6698^{*}$ & $-1.2699^{*}$ \\
\hline & $(0.1487)$ & $(0.5054)$ & $(0.4705)$ & $(0.6015)$ & $(0.3605)$ & $(0.7548)$ \\
\hline \multicolumn{7}{|c|}{ Insurance Design } \\
\hline \multirow{2}{*}{ DI Dummy } & $-0.0316^{* * *}$ & -0.0116 & $-0.0233^{*}$ & -0.0201 & $-0.0588^{* *}$ & 0.0458 \\
\hline & $(0.0082)$ & $(0.0216)$ & $(0.0128)$ & $(0.0245)$ & $(0.0205)$ & $(0.0306)$ \\
\hline \multirow{2}{*}{$\begin{array}{l}\text { Jointly Funded } x \\
\text { DI Dummy }\end{array}$} & $0.0297^{* *}$ & -0.0076 & $0.0397^{*}$ & 0.0373 & $0.0482^{* *}$ & 0.0067 \\
\hline & $(0.0116)$ & $(0.0280)$ & $(0.0222)$ & $(0.0320)$ & $(0.0235)$ & $(0.0395)$ \\
\hline \multicolumn{7}{|l|}{ Macroeconomic } \\
\hline \multirow{2}{*}{ Gdp Growth } & -0.0762 & $-0.2890^{* *}$ & 0.0212 & $0.2127^{*}$ & -0.1039 & 0.2571 \\
\hline & $(0.0497)$ & $(0.1035)$ & $(0.0867)$ & $(0.1098)$ & $(0.1550)$ & $(0.3053)$ \\
\hline \multirow{2}{*}{ Inflation } & $-0.0932^{* *}$ & -0.0298 & $-0.1794^{*}$ & -0.0633 & $-0.2845^{* *}$ & $0.2991^{* *}$ \\
\hline & $(0.0445)$ & $(0.1106)$ & $(0.0931)$ & $(0.1274)$ & $(0.1279)$ & $(0.1367)$ \\
\hline \multirow{2}{*}{ Constant } & $0.7830^{* * *}$ & -0.0520 & $0.8764^{* * *}$ & $0.8350^{* * *}$ & $-0.2966^{* * *}$ & $1.1522^{* * *}$ \\
\hline & $(0.0246)$ & $(0.0548)$ & $(0.0447)$ & $(0.0671)$ & $(0.0750)$ & $(0.1098)$ \\
\hline R-squared & 0.496 & 0.621 & 0.615 & 0.667 & 0.690 & 0.615 \\
\hline Adj. R-squared & 0.490 & 0.617 & 0.611 & 0.664 & 0.687 & 0.611 \\
\hline No. of Obs & 3965 & 3965 & 3965 & 3965 & 3965 & 3948 \\
\hline
\end{tabular}

${ }^{*} \mathrm{p}<.1,{ }^{* *} \mathrm{p}<.05,{ }^{* * *} \mathrm{p}<.001$ (DI Dummy is deposit Insurance Dummy) 
Relative to privately funded schemes, the study finds that the jointly funded schemes reduce the decreasing effect of deposit insurance on leverage. This effect is significant and in both cases the effect on the leverage ratio is negative. These results are reflected in the model that tests for the effect of funding choice on the short-term funding as well. The effect of total deposit ratio is not significant at $10 \%$ level to make an inference and decomposing the total deposit ratio into its determinant ratios reveals the same effect. The saving deposit ratios exhibit a negative reaction to deposit insurance. If the deposit insurance scheme is funded jointly, the effect is reduced to only a $1 \%$ decrease rather than a $5 \%$ decrease if not funded jointly.

The administration of the explicit deposit insurance scheme is officially done either privately or jointly. In Asian countries implementing deposit insurance, the majority of deposit insurance schemes are administered officially. The least number of countries have deposit insurance schemes that are privately administered. The effect of the type of administration is reported in Table 7. The models reported use interaction terms of the administration type with the deposit insurance dummy. Relative to countries administered officially the effect of joint and private administration has a more significant effect on the leverage ratio. The privately administered scheme has a more significant effect on the leverage decreasing the leverage the most at $1 \%$ significance level. The non-deposit ratio falls more under joint administration. Intuitively speaking, the government guarantee instils more confidence within the depositors and should have a positive effect on the deposit ratio. The effect of type of administration is most prominent with the deposit ratio. The jointly administered deposit insurance increases the deposit ratio where as those insurance programs that are administered privately result in a reduction in the total deposits to assets ratio. Jointly administered deposit insurance, however, have a stronger effect on the deposit ratio of banks thus indicating improved ability to generate confidence of deposits using joint administration. Further breakdown of total consumer deposits reveals that the effect of deposit insurance is more with jointly administered schemes compared to both privately and officially administered schemes. 


\section{Table 7: Design Feature Administration}

The estimated model is Yict $=\beta 0+\beta 1$ Profitict- $1+\beta 2$ Taxict- $1+\beta 3$ OverHeadict- $1+\beta 4$ Dividendict $-1+\beta 5$ DepositlnsurancexAdmin isteredJointlyict $+\beta 6$ DepositlnsurancexAdministeredPrivatelyict $+\beta 7 \operatorname{Ln}($ Size)ict- $1+\beta 8$ Liquidityict- $1+\delta c$ CountryDummyct $\gamma t$ TimeDummyt+ $\beta 9 \mathrm{Gdpct}+\beta 10$ Inflationct+cict. The level dependent variable Yict takes the form of leverage ratio which is the total liabilities to total assets, Non deposit liabilities/Total Asset, Short term funding ratio is short term deposits and other shortterm liabilites to total asset and finally the deposit to total asset ratio. The Profit is defined as the net income to total assets. Tax is $\log (\operatorname{Tax}$ expenses). Overhead is the personal expense and other noninterest expense to total asset.Liquidity is the total liquid assets to total assets. The Dividend is a 0 or 1 dummy with 1 representing dividend payout year. Size is the log of total assets to total Gdp. The Administered Jointly dummy is interacted with the deposit insurance dummy. The Privately Administered dummy is also interacted with the deposit insurance dummy. The reference dummy is through government administration. The sample of banks are those using explicit deposit insurance. Robust standard errors are reported clustered at bank level.

\begin{tabular}{|c|c|c|c|c|c|c|}
\hline & $\begin{array}{l}\text { Leverage } \\
\text { Ratio }\end{array}$ & $\begin{array}{l}\text { NonDeposit } \\
\text { Ratio }\end{array}$ & $\begin{array}{l}\text { ShortTerm } \\
\text { FundingRatio }\end{array}$ & $\begin{array}{l}\text { Deposit } \\
\text { Ratio }\end{array}$ & $\begin{array}{c}\text { Saving } \\
\text { Deposit } \\
\text { Ratio }\end{array}$ & $\begin{array}{c}\text { Term } \\
\text { Deposit } \\
\text { Ratio } \\
\end{array}$ \\
\hline & Level & Level & Level & Level & Level & Level \\
\hline \multicolumn{7}{|l|}{$\begin{array}{l}\text { Bank Specific } \\
\text { Variables }\end{array}$} \\
\hline \multirow{2}{*}{ Size } & $0.0126^{* * *}$ & 0.0004 & $0.0094^{* * *}$ & $0.0122^{* * *}$ & $0.0136^{* * *}$ & $-0.0135^{* *}$ \\
\hline & $(0.0014)$ & $(0.0027)$ & $(0.0022)$ & $(0.0033)$ & $(0.0023)$ & $(0.0043)$ \\
\hline \multirow{2}{*}{ Profit } & $-1.8926^{* * *}$ & 0.2264 & $-1.9875^{* * *}$ & $-2.1189^{* * *}$ & 0.2137 & $-2.5985^{* * *}$ \\
\hline & $(0.2488)$ & $(0.4205)$ & $(0.4113)$ & $(0.5310)$ & $(0.3905)$ & $(0.6906)$ \\
\hline \multirow{2}{*}{$\operatorname{Tax}$} & $-0.0052^{* * *}$ & $0.0037^{*}$ & $-0.0080^{* * *}$ & $-0.0089^{* * *}$ & $0.0046^{* *}$ & $-0.0135^{* * *}$ \\
\hline & $(0.0009)$ & $(0.0020)$ & $(0.0016)$ & $(0.0023)$ & $(0.0017)$ & $(0.0032)$ \\
\hline \multirow{2}{*}{ Dividend } & $0.0105^{* *}$ & $-0.0147^{*}$ & $0.0191^{* * *}$ & $0.0252^{* *}$ & 0.0084 & $0.0178^{*}$ \\
\hline & $(0.0034)$ & $(0.0078)$ & $(0.0057)$ & $(0.0090)$ & $(0.0085)$ & $(0.0106)$ \\
\hline \multirow{2}{*}{ Liquidity } & 0.0154 & -0.0072 & 0.0172 & 0.0226 & $0.0984^{* * *}$ & $-0.2216^{* * *}$ \\
\hline & $(0.0139)$ & $(0.0326)$ & $(0.0230)$ & $(0.0337)$ & $(0.0269)$ & $(0.0436)$ \\
\hline \multirow{2}{*}{ Overhead } & 0.1786 & 0.5274 & -0.2404 & -0.3488 & $0.6848^{*}$ & $-1.2734^{*}$ \\
\hline & $(0.1500)$ & $(0.5057)$ & $(0.4726)$ & $(0.6030)$ & $(0.3610)$ & $(0.7575)$ \\
\hline \multicolumn{7}{|l|}{$\begin{array}{l}\text { Insurance } \\
\text { Design }\end{array}$} \\
\hline \multirow{2}{*}{ DI Dummy } & $-0.0139^{* *}$ & -0.0161 & 0.0004 & 0.0022 & $-0.0301^{* *}$ & $0.0502^{* *}$ \\
\hline & $(0.0066)$ & $(0.0136)$ & $(0.0124)$ & $(0.0159)$ & $(0.0116)$ & $(0.0191)$ \\
\hline \multirow{2}{*}{$\begin{array}{l}\text { Admin Jointly } x \\
\text { DI Dummy }\end{array}$} & $-0.0321^{* *}$ & $-0.2949^{* * *}$ & $0.0393^{*}$ & $0.2627^{* * *}$ & $-0.4015^{* * *}$ & $0.4471^{* * *}$ \\
\hline & $(0.0144)$ & $(0.0331)$ & $(0.0233)$ & $(0.0422)$ & $(0.0602)$ & $(0.0554)$ \\
\hline \multirow{2}{*}{$\begin{array}{l}\text { Admin Privately } x \\
\text { DI Dummy }\end{array}$} & $-0.0660^{* * *}$ & 0.0061 & $-0.0481^{* * *}$ & $-0.0721^{* * *}$ & $-0.1211^{* * *}$ & $0.1869^{* * *}$ \\
\hline & $(0.0093)$ & $(0.0194)$ & $(0.0141)$ & $(0.0216)$ & $(0.0271)$ & $(0.0438)$ \\
\hline \multicolumn{7}{|l|}{ Macroeconomic } \\
\hline \multirow{2}{*}{ Gdp Growth } & -0.0615 & $-0.2934^{* *}$ & 0.0441 & $0.2319^{* *}$ & -0.0808 & 0.2745 \\
\hline & $(0.0491)$ & $(0.1047)$ & $(0.0875)$ & $(0.1101)$ & $(0.1449)$ & $(0.2937)$ \\
\hline \multirow{2}{*}{ Inflation } & $-0.1276^{* *}$ & -0.0215 & $-0.2234^{* *}$ & -0.1061 & $-0.3407^{* *}$ & $0.2996^{* *}$ \\
\hline & $(0.0458)$ & $(0.1095)$ & $(0.0941)$ & $(0.1243)$ & $(0.1276)$ & $(0.1400)$ \\
\hline \multirow{2}{*}{ Constant } & $0.7924^{* * *}$ & $0.2483^{* * *}$ & $0.8079^{* * *}$ & $0.5441^{* * *}$ & 0.0678 & $0.7059^{* * *}$ \\
\hline & $(0.0238)$ & $(0.0555)$ & $(0.0435)$ & $(0.0668)$ & $(0.0921)$ & $(0.1076)$ \\
\hline R-squared & 0.494 & 0.621 & 0.614 & 0.667 & 0.689 & 0.616 \\
\hline Adj. R-squared & 0.488 & 0.617 & 0.609 & 0.663 & 0.686 & 0.612 \\
\hline No. of Obs & 3967 & 3967 & 3967 & 3967 & 3967 & 3950 \\
\hline
\end{tabular}

${ }^{*} \mathrm{p}<.1,{ }^{* *} \mathrm{p}<.05,{ }^{* * *} \mathrm{p}<.001$ (DI Dummy is deposit Insurance Dummy) 


\section{Conclusion}

The paper analysed the effect of explicit deposit insurance on banks' liability structure and found the evidence to support the theory of banks' liability structure proposed by Sundaresan and Wang (2014). The study finds a visible shift in funds in Asian countries towards term deposits as a result of explicit deposit insurance. With financing constraints due to underdeveloped capital markets, a positive shift towards long term investment would make more funds available to banks for long term lending and contribute to a country`s development.

The cumulative effect of deposit liabilities and non-deposit liabilities determines the overall direction of the leverage ratio. For Asian banks analysed in this study it is found that the leverage ratio maintained by the banks falls after the implementation of the deposit insurance scheme. This result is counter to what Sundaresan and Wang (2014) predict about the leverage ratio increasing. According to the theory, the predicted deposit ratio increases; however, a decrease of the non-deposit liabilities ratio is higher. In line with previous studies, the effect of the explicit deposit insurance on deposit growth is not significant. However, when it comes to decomposing the total customer deposits into its different types, the paper finds evidence of an increase in deposit growth of term deposits as a result of explicit deposit insurance. The current and saving deposits ratios fall. It finds evidence of a shift of deposit liabilities from short-term deposit liabilities to long term fixed deposits. In Asian banks, $60 \%$ of deposits, on average, are term deposits, so the total customer deposits increase overall.

The paper also finds evidence of tax expense on a bank's liability structure, as is proposed by the model. The deposit ratio is found to have a negative relationship with the tax expense and an increase in the tax expenses results in an increase in the bank's debt liabilities. The paper finds that the design features have significant effect on bank's liability structure. Evidence stresses that the coverage per capita has a positive relationship with the leverage ratio. Allocating the right amount of coverage for the deposit insurance program is essential as it determines how bank leverage is determined and does not expose the bank to undue risk. In implementing explicit deposit insurance schemes, the choice of who owns the program, the funding source, and the administration of the program all have implications on a bank's leverage and financing mix used by the bank. 


\section{References}

1. Assa, H., \& Okhrati, R. (2018). Designing Sound Deposit Insurances. Journal of Computational and Applied Mathematics, 327, 226-242.

2. Bradley, C. M., \& Shibut, L. (2006). The Liability Structure of FDIC Insured Institutions: Changes and Implications. FDIC Banking Review., 18, 1.

3. Buser, S. A., Chen, A. H., \& Kane, E. J. (1981). Federal deposit insurance, regulatory policy, and optimal bank capital. The Journal of Finance, 36(1), 51-60.

4. Chernykh, L., \& Cole, R. A. (2011). Does Deposit Insurance Improve Financial Intermediation? Evidence from the Russian experiment. Journal of Banking \& Finance, 35(2), 388-402.

5. Cull, R., Senbet, L. W., \& Sorge, M. (2002). The Effect of Deposit Insurance on Financial Depth: A Cross-Country Analysis. The Quarterly Review of Economics and Finance, 42(4), 673-694.

6. Demirgüç-Kunt, A., \& Detragiache, E. (2002). Does Deposit Insurance increase Banking System Stability? An Empirical Investigation. Journal of monetary economics, 49(7), 1373-1406.

7. Demirgüç-Kunt, A., \& Kane, E. J. (2002). Deposit Insurance around the Globe: Where does it work? Journal of Economic Perspectives, 16(2), 175-195.

8. Demirgüç-Kunt, A., \& Huizinga, H. (2004). Market discipline and deposit insurance. Journal of Monetary Economics, 51(2), 375-399.

9. Demirgüç-Kunt, A. (2013). Re-examining the role of the state in the financial sector. Journal of Financial Stability, 4(9), 731-732.

10. Diamond, D. W., \& Dybvig, P. H. (1983). Bank runs, deposit insurance, and liquidity. Journal of Political Economy, 91(3), 401-419.

11. Fueda, I., \& Konishi, M. (2007). Depositors' response to deposit insurance reforms: evidence from Japan, 1990-2005. Journal of Financial Services Research, 31(2-3), 101-122.

12. Goldstein, I., \& Pauzner, A. (2005). Demand-deposit contracts and the probability of bank runs. The Journal of Finance, 60(3), 1293-1327.

13. Gonzalez, F. (2005). Bank regulation and risk-taking incentives: An international comparison of bank risk. Journal of Banking \& Finance, 29(5), 11531184.

14. Gropp, R., \& Heider, F. (2010). The determinants of bank capital structure. Review of Finance, 14(4), 587-622.

15. Igbinosa, S., Sunday, O., \& Babatunde, A. (2017). Empirical Assessment on Financial Regulations and Banking Sector Performance. Journal of Central Banking Theory and Practice, 6(3), 143-155. 
16. Ioannidou, V., \& De Dreu, J. (2019). The Impact of Explicit Deposit Insurance on Market Discipline. Panel Data Econometrics, (pp. 839-864). Academic Press.

17. Keiko, M.?, \& Masahiro, H.? (2004). End of the Convoy system and the surge of Market Discipline: Evidence from Japanese small Financial Institutions (No. 105). Economic and Social Research Institute (ESRI).

18. Kim, I., \& Han, Y. (2014). Deposit insurance, banks' moral hazard, and regulation: Evidence from the ASEAN countries and Korea. Emerging Markets Finance and Trade, 50(6), 56-71.

19. Leland, H. E. (1994). Corporate debt value, bond covenants, and optimal capital structure. The Journal of Finance, 49(4), 1213-1252.

20. Martinez Peria, M. S., \& Schmukler, S. L. (2001). Do Depositors Punish Banks for Bad Behavior? Market discipline, Deposit Insurance, and Banking Crises. The Journal of Finance, 56(3), 1029-1051.

21. Merton, R. C. (1977). An analytic derivation of the cost of deposit insurance and loan guarantees an application of modern option pricing theory. Journal of Banking \& Finance, 1(1), 3-11.

22. Murata, K., \& Hori, M. (2004), End Of The Convoy System And The Surge Of Market Discipline: Evidence From Japanese Small Financial Institutions, Esri Discussion Paper No. 105 Tokyo Economic And Social Research Institute

23. Nys, E., Tarazi, A., \& Trinugroho, I. (2015). Political connections, Bank Deposits, and Formal Deposit Insurance. Journal of Financial Stability, 19, 83 104.

24. Park, S. (1995). Market discipline by depositors: Evidence from reduced-form equations. The Quarterly Review of Economics and Finance, 35, 497-514

25. Qian, N., Zhang, K., \& Zheng, C. (2017). How Do Regulatory Ability and Banking Market Structure Affect Explicit Deposit Insurance Scheme Adoption and Banks' Risk Taking?. Available at http://dx.doi.org/10.2139/ ssrn.3060943

26. Sundaresan, S., \& Wang, Z. (2014). Bank Liability Structure. Columbia Business School Research Paper No. 14-41

27. Tsuru, K. (2003). Depositors' selection of banks and the deposit insurance system in Japan: Empirical evidence and its policy implications. Research Institute of Economy, Trade and Industry (RIETI) Discussion Paper Series, (03-E), 024. 